\title{
Objectives of Islamic banks: a missive from mission statements and stakeholders' perceptions
}

\author{
Dr. Ishfaq Ahmed (Ph.D. Management) \\ Assistant Professor \\ Hailey College of Commerce, University of the Punjab, Lahore, Pakistan \\ Email: ishfakahmed@gmail.com, Call:+92 (0) 3334710476 \\ Muhammad Musarrat Nawaz \\ Assistant Professor \\ Department of Commerce, University of the Punjab Gujranwala Campus, Gujranwala, Pakistan \\ Email: musaratnawaz@gmail.com \\ Dr. Rizwan Qaisar Danish \\ Assistant Professor \\ Hailey College of Commerce, University of the Punjab, Lahore, Pakistan \\ Email: rdanish@yahoo.co.uk \\ Ahmad Usman \\ Ph.D. Scholar \\ Faculty of Business \& Economics, University Malaysia Sarawak, Kuching, Malaysia \\ Email: a.usman@live.com \\ Muhammad Zeeshan Shaukat \\ Ph.D. scholar \\ Faculty of Management, Universiti Teknologi Malaysia, Johor Bahru, Malaysia \\ Email: mzeeshan.shaukat@gmail.com
}




\section{Objectives of Islamic banks: a missive from mission statements and stakeholders' perceptions}

\section{Purpose \& Significance:}

It is believed that the core aim of Islamic institution is idiosyncratic from conventional business entities. Considering this presumption, this study entails to reveal the understandings of various stakeholders about objectives of Islamic banks.

\section{Methodology:}

The research endeavor is based on the findings of two distinctive studies, where study-1 was aimed at investigating the communication of objectives through mission statements of Islamic banks and conventional banks with window operations. Here mission statements were analyzed using content analysis and readability \& understandability tests. The study-2, on the other hand, was aimed at investigating the understandings of various stakeholders, both internal (employees) and external (Muslim \& non-Muslim customers of both Islamic and conventional banks, employees \& management of conventional banks, and business students). 370 responses were received and analyzed in this study.

\section{Findings:}

Findings (study-1) unveil, the fact, that the mission statements of Islamic banks working in Pakistan are not good at communicating the corporate goals clearly. Out of ten banks investigated for study-I, it is evident that only one bank (HBL, with window operations) was at par with readability threshold standards. Thus it was imperative to share that mission statements of Islamic banks are difficult to read and comprehend. Study-2, adds further by revealing that most of the stakeholders are not clear about the objectives of these banks, while customers of conventional banks don't value the distinctive objectives of Islamic banks.

\section{Implications:}

This study leaves a valuable message for the policy makers and top management of Islamic banks, by focusing on the unattended part on their end, i.e. quality of mission statements and stakeholders' perception about the objectives of their organization. Thus highlighting the needs of greater emphasis on the communication flow to stakeholders, as the clarity of business purpose may change the way customers react towards the business and opt for banking - customer relation in future.

\section{Originality:}

This study covers a multi-dimensional investigation of the understanding and communication of objectives of Islamic banks. There is dearth of literature focusing on the aspects of content analysis, mission statement readability \& understandability and investigation of stakeholders' perception in tandem. 